\title{
Relações conceituais entre o design da informação, a literatura infantil e os fundamentos da narrativa
}

\author{
Conceptual relations between information design, children's literature and the \\ fundamentals of storytelling
}

Guilherme Mendes Cahú Costa, Solange G. Coutinho

design da informação, literatura infantil, livro ilustrado, narrativa

\begin{abstract}
Este artigo apresenta relações conceituais entre algumas definições do Design da Informação com as características dos livros infantis e os fundamentos da narrativa. Objetivamos fornecer um ferramental teórico para o campo do Design da Informação de forma a aprofundar estudos sobre a Literatura Infantil, contribuindo para a eficiência dos processos de análise e configuração dos livros ilustrados, bem como de outras formas de transmissão de histórias. Para tal, uma revisão sistemática de literatura foi conduzida, revelando uma lacuna de estudos que realizassem essas relações conceituais. Após abordagem das definições e características destes campos por método dialético, apresentamos figuras comparativas para demonstrar as relações encontradas.
\end{abstract}

information design, children's literature, picture book, storytelling

This article presents conceptual relationships between certain definitions of Information Design and the characteristics of children's books and the fundamentals of storytelling. We aim to provide a theoretical tool for the field of information design in order to broaden studies on children's literature, thereby contributing to the efficiency of the processes involved in the analysis and configuration of illustrated books, as well as other forms of transmitting stories. To this end, a systematic literature review was undertaken, which has revealed a lack of studies conducted on these conceptual relationships. After addressing the definitions and characteristics of these fields through dialectics, we present comparative figures to demonstrate the relationships encountered.

\section{Introdução}

Este artigo surgiu com o propósito de explorar relações entre os campos do Design da Informação (DI) e da Literatura Infantil. Neste processo, encontrou-se também relações com os fundamentos da narrativa, úteis aos livros infantis.

Motivou esta pesquisa compreender se existe uma relação entre livros infantis e o campo do DI. Para tal, conduziu-se uma revisão sistemática de literatura utilizando-se os procedimentos de Gil (2008), abrangendo o período entre 2016 e 2021, onde investigou-se quais artigos estabelecem relações conceituais ou definição entre o Design da Informação e a Literatura Infantil.

Anais do $10^{\circ} \mathrm{CIDI}$ e $10^{\circ} \mathrm{CONGIC}$

Kelli C.A.S. Smythe, Rafael de Castro Andrade (orgs.)

Sociedade Brasileira de Design da Informação - SBDI

Curitiba | Brasil | 2021
Proceedings of the $10^{\text {th }} \mathrm{CIDI}$ and $10^{\text {th }} \mathrm{CONGIC}$

Kelli C.A.S. Smythe, Rafael de Castro Andrade (orgs.)

Sociedade Brasileira de Design da Informação - SBDI Curitiba | Brazil | 2021 
Num primeiro momento, verificou-se a existência de publicações relacionando a Literatura Infantil ao campo do Design da Informação, na sequência conduziu-se à revisão sistemática de literatura. Este artigo encontra-se organizado em oito tópicos incluindo a introdução, a saber: (2) descreve-se a metodologia adotada; (3) discute-se a revisão de literatura; (4) explora-se as definições de Design da Informação; (5) define-se o livro infantil ilustrado; (6) descreve-se as características da Literatura Infantil e os fundamentos da narrativa; (7) apresenta-se as relações do Design da Informação com a Literatura Infantil e os fundamentos da narrativa; e finalmente (8) as considerações finais.

Observou-se que há uma lacuna, no corpus pesquisado, de estudos que explicitamente situem a Literatura Infantil como objeto de estudo do DI. Essa problemática já é compartilhada entre alguns pesquisadores da área, quanto ao livro em geral, como Souza et al. (2018, p. 162), que afirmam: "O livro é um artefato informacional estruturado pelo projeto gráfico. O designer medeia os elementos do projeto e o seu conteúdo textual ou pictórico, constituindo sua atividade através das decisões projetuais."

Apesar do livro ter seu conteúdo estruturado pelo designer que desenvolve seu projeto gráfico, o conteúdo textual e imagético não é necessariamente criado por ele, mas sim pelo escritor e pelo ilustrador - no caso do livro infantil, exceto se o designer também assumir estas funções. Se o ponto de partida do Design da Informação, para Redig (2004), não é o emissor, mas sim "[...] quem determina o conteúdo da mensagem [...]" (Ibid., p. 62), então é justo levar em conta a configuração desse conteúdo informacional, considerando-se que o livro ilustrado é um meio de comunicação do escritor e ilustrador com seus leitores, e por sua vez pode se configurar como um objeto de estudo da disciplina do DI.

\section{Metodologia}

Para a primeira fase, utilizamos os procedimentos de Gil (2008) para uma revisão sistemática de literatura com uma simplificação a partir do item 5 , apresentados na lista a seguir. Na segunda fase, abordamos as definições trazidas através do método dialético e discutimos as relações conceituais através do método comparativo, com o auxílio de figuras.

Os procedimentos para a revisão de literatura foram:

\section{Formulação do problema}

Quais artigos estabelecem relações conceituais ou de definição entre o Design da Informação e a Literatura Infantil? Relações esperadas eram explicitamente do objetolivro ilustrado ou do conteúdo texto-imagem em função do DI.

\section{Elaboração do plano de trabalho}

Pesquisar usando palavras-chave em português e em inglês separadamente, utilizando operadores booleanos ${ }^{1}$.

\footnotetext{
1 Operadores lógicos como "AND" e "OR" são usados em pesquisa em computadores (Cambridge University Press, 2021). "AND" retorna resultados onde todas as variáveis associadas pelo operador aparecem, enquanto "OR" retorna resultados onde ao menos uma variável associada aparece.
} 
Coletar artigos que permitam o download do texto completo, em língua portuguesa ou inglesa, publicados entre 2016 e 2021.

Analisar os artigos coletados.

\section{Identificação das fontes}

InfoDesign - Revista Brasileira de Design da Informação.

Selected Readings of the Information Design International Conference.

Estudos em Design.

Blucher Design Proceedings.

Periódicos no Portal de Periódicos CAPES.

Periódicos no repositório Scielo.

\section{Localização das fontes e obtenção do material}

InfoDesign e Estudos em Design são alcançadas pelo Portal de Periódicos CAPES.

Selected Readings of the Information Design International Conference não é indexado e precisou de busca manual.

Blucher Design Proceedings é indexado pelo Google Scholar.

\section{Filtragem avançada do material}

Remoção de duplicatas.

Seleção de textos por relevância conforme análise do título, resumo e palavras-chave que contenham indícios de atendimento ao problema formulado para esta revisão. Leitura aprofundada dos textos selecionados.

\section{Discussão dos achados}

Selecionamos a revista InfoDesign - Revista Brasileira de Design da Informação e Estudos em Design por serem publicações bem avaliadas pela Capes, de conceitos B1 e A2 respectivamente, bem como o fato da primeira ser focada no campo do DI. A InfoDesign é indicada pela Sociedade Brasileira de Design da Informação (SBDI), assim como o Selected Readings of the Information Design International Conference. Neste, realizamos uma busca manual por não haver indexação. Procuramos também no Blucher Design Proceedings, indexado pelo Google Scholar, por reunir publicações dos diversos congressos de Design realizados no Brasil, e nos periódicos indexados pelo Portal de Periódicos CAPES - que já indexa a Estudos em Design e que abrange o indexador Gale, consequentemente alcançando a revista InfoDesign - e no repositório Scielo.

Nos periódicos em língua portuguesa, utilizamos palavras-chave em ambas as línguas em buscas diferentes. Nas publicações em língua inglesa, utilizamos apenas palavras-chave em inglês. Procuramos publicações realizadas nos últimos cinco anos, entre 2016 e 2021.

As palavras-chave inicialmente utilizadas geraram resultados generalizados e irrelevantes, por isso foram refinadas e seu número reduzido, encontrando-se na figura 1 junto com os operadores booleanos utilizados na busca. Termos associados à Literatura Infantil foram relacionados entre si pelo operador $\mathrm{OR}$ e este conjunto foi relacionado ao termo design da informação - ou information design - pelo operador AND. Para a busca no Blucher Design Proceedings pelo Google Scholar, adicionamos o nome do periódico entre aspas associado ao 
operador AND. Existem mais palavras em inglês devido aos sinônimos relevantes que ocorrem neste idioma.

Figura 1: Palavras-chave e operadores booleanos utilizados na busca.

\section{Operadores booleanos Palavras em português Palavras em inglês}

OR

\author{
livro infantil \\ literatura infantil \\ literatura para crianças \\ livro para crianças \\ livro ilustrado \\ livro com ilustração
}

AND children's books children's literature books for children illustrated book illustrated-book picture book picture-book picturebook

information design

\section{Discussão da revisão de literatura}

A figura 2 apresenta o resultado da coleção de artigos. Após leitura completa e aprofundada dos 14 artigos resultantes após seleção por relevância, constatamos que nenhum posicionou o objeto-livro ilustrado ou o conteúdo texto-imagem em função dos conceitos do Design da Informação. 
Figura 2: Resultado da coleção de artigos.

\begin{tabular}{|c|c|c|c|c|c|c|}
\hline \multirow{2}{*}{$\begin{array}{l}\text { Repositório } \\
\text { ou indexador }\end{array}$} & \multirow{2}{*}{$\begin{array}{l}\text { Alvo } \\
\text { de busca }\end{array}$} & \multicolumn{2}{|c|}{ Resultados válidos } & \multicolumn{3}{|c|}{ Total } \\
\hline & & Português & Inglês & $\begin{array}{l}\text { com } \\
\text { duplicatas }\end{array}$ & $\begin{array}{l}\text { sem } \\
\text { duplicatas }\end{array}$ & $\begin{array}{l}\text { após seleção } \\
\text { por relevância }\end{array}$ \\
\hline $\begin{array}{l}\text { Portal de } \\
\text { Periódicos } \\
\text { CAPES }\end{array}$ & $\begin{array}{l}\text { InfoDesign } \\
\text { Estudos } \\
\text { em Design } \\
\text { Todos } \\
\text { os outros } \\
\text { periódicos } \\
\text { alcançáveis }\end{array}$ & 3 & 18 & 21 & 18 & 3 \\
\hline Scielo & $\begin{array}{l}\text { Todos os } \\
\text { periódicos } \\
\text { alcançáveis }\end{array}$ & 1 & 2 & 3 & 2 & 0 \\
\hline $\begin{array}{l}\text { Google } \\
\text { Scholar }\end{array}$ & $\begin{array}{l}\text { Blucher } \\
\text { Design } \\
\text { Proceedings }\end{array}$ & 11 & 6 & 17 & 12 & 7 \\
\hline $\begin{array}{l}\text { Independente, } \\
\text { não-indexado }\end{array}$ & $\begin{array}{l}\text { Selected } \\
\text { Readings } \\
\text { of the } \\
\text { Information } \\
\text { Design } \\
\text { International } \\
\text { Conference }\end{array}$ & - & 5 & 5 & 5 & 4 \\
\hline Total & - & 15 & 31 & 46 & 37 & 14 \\
\hline
\end{tabular}

Apesar da carência de artigos com a abordagem esperada, alguns textos merecem menção por trazerem conceitos de Design próximos ao objeto de estudo ou por adentrarem na configuração das mensagens ou dos meios.

Franco (2018) utilizou conceitos do Design da Informação, seu método projetual e de análise do conteúdo gráfico de seu objeto de estudo, mesmo não apresentando uma relação direta do objeto-livro com os conceitos do DI. Lacerda e Farbiarz (2016) abordaram o campo do Design como mediador do livro entre seu conteúdo - texto e imagem - e o leitor através do projeto gráfico. Apesar de analisarem o conteúdo do livro para categorizar relações texto-imagem, a pesquisa não conecta diretamente o objeto-livro com conceitos do Design da Informação. Souza et. al. (2016a) discorreram sobre as características configurativas dos livros ilustrados e das histórias em quadrinhos em geral, discutindo como ambos são pertencentes ao medium dos comics. Este foi o artigo que mais se aprofundou na análise da configuração, apesar de não associá-los a conceitos do DI. 
Apesar da inexistência de relações conceituais nos textos analisados, não consideramos isso como negativo porque não comprometeu a qualidade dos artigos. Ainda assim, revela uma lacuna teórica que, se abordada, permitirá o embasamento de estudos ainda mais aprofundados na análise do livro ilustrado sob o olhar do Design da Informação.

A seguir apresentam-se os conceitos desta área, da Literatura Infantil e dos fundamentos da narrativa para discutirmos suas relações conceituais.

\section{Definições do design da informação}

Para compreender como a Literatura Infantil se situa nesse campo, investigou-se definições sobre o Design da Informação em busca de indícios de potenciais relações entre o DI e a Literatura Infantil.

Segundo Jacobson (1999, p. 4, tradução nossa), o propósito do Design da Informação, “[...] é o arranjo e uso sistemático de veículos, canais e sinais [tokens] de comunicação para aumentar o entendimento daqueles que estão participando em uma conversa ou discurso específico." Este foco no aumento do entendimento demonstra atenção ao receptor da mensagem e com a contribuição que ela terá para o indivíduo.

Para Horn (1999, p. 16, tradução nossa), "Design da informação é definido como a arte e a ciência de preparar informação para que possa ser usada por seres humanos com eficiência e eficácia." O autor leva em consideração o uso da informação, nos fazendo ponderar que ela se dispõe a alguma utilidade, munindo o indivíduo para tomar uma decisão ou realizar uma ação.

Já Shedroff (1999) trata o Design da Informação como uma parte do que chama de Information Interaction Design, junto aos campos de Design de Interação e Design Sensorial. Ele define que esse tipo de Design composto trata de criar "[...] interações, apresentações e experiências para os outros" (Ibid., p. 267, tradução nossa). Ressaltamos nisso o caráter sensorial, da experiência estética, próprio das Artes, sendo abordado no Design. Para o DI, especificamente, ele define que "a disciplina aborda a organização e a apresentação de dados sua transformação em informação com valor e significado" (Ibid., p. 268, tradução nossa), considerando que dados são transformados em informação apenas quando são colocados em contexto e thes é agregado valor.

Para Souza et al. (2016b, p. 108), "em sua prática, o design da informação determina-se através de atuações pragmáticas, enfatizando o uso, o usuário e a sua transformação de atitude." Isso nos remete às palavras de Horn (1999) e Jacobson (1999) sobre a informação interferir no indivíduo, melhorando seu entendimento ou dispondo-se ao uso eficiente e eficaz.

Conforme Redig (2004, p. 60): "Todo Design é de Informação." Segundo ele, dez características condicionadas a três grupos definem os artefatos informacionais e contribuem para um bom processo comunicativo: o Design da Informação existe condicionado ao destinatário - foco no receptor -, à forma - sendo análogo, claro, conciso, enfático, coloquial, consistente e cordial - e ao tempo - sendo a comunicação oportuna e estável, considerando-se a estabilidade como uma consistência em função do tempo. A observância a essas 
características garante uma boa comunicação com o usuário - no caso desta pesquisa, entendido como o leitor. Se todo Design é de Informação, então qualquer artefato pode ser analisado sob essas características. Adicionalmente, traz à tona o caráter cognitivo em que opera o DI, em equivalência a Jacobson (1999), que considera a área se relacionando mais no campo do significado. Em conjunto, essas considerações nos remetem ao foco no receptor e na configuração da mensagem a ser transmitida.

Por fim, segundo a Sociedade Brasileira de Design da Informação:

Design da Informação é uma área do Design cujo propósito é a definição, planejamento e configuração do conteúdo de uma mensagem e dos ambientes em que ela é apresentada, com a intenção de satisfazer as necessidades informacionais dos destinatários pretendidos e de promover eficiência comunicativa. (SBDI, 2020)

Destacamos aqui a menção às necessidades informacionais dos destinatários e à eficiência comunicativa. O primeiro diz respeito à atenção ao indivíduo destinatário, consideração feita nas definições anteriormente abordadas e presente no cerne da atividade do Designer. O segundo remete mais fortemente a Horn (1999) sobre o cuidado para que a informação seja usada com eficiência e eficácia.

\section{Livros infantis ilustrados}

A Literatura Infantil é fortemente caracterizada pela presença de imagens no livro para crianças. Inicialmente com imagens para auxiliar na compreensão e no processo de aprendizado, tanto de materiais didáticos quanto de contos moralistas - estes últimos uma marca do passado - os livros infantis evoluíram para dispor de melhor diálogo texto-imagem a partir do fim do século XIX na Europa (Salisbury, 2004) e da segunda metade do século XX no Brasil (Lajolo \& Zilberman, 2007; 2017).

Diante da profusão de produções literárias, duas classificações gerais costumam ser feitas quanto aos livros: livros com ilustração, em que a imagem é redundante ao texto e é dispensável à contação da história; e livros ilustrados, em que imagem e texto dialogam entre si para produzir um sentido único, só sendo possível compreender a história com a presença dos dois (Nikolajeva \& Scott, 2011; Linden, 2011; Fleck et al., 2016; Wu, 2018).

Quanto à função da literatura, observa-se na abordagem que realiza dos aspectos subjetivos e complexos da vida humana, não sendo eles ensinados pela escola, formadora do indivíduo, e muitas vezes nem mesmo pela família. A abordagem desses aspectos foge à visão idealizada de um mundo regido por normas definidas, próprio da visão didática e racionalista e que termina fixando-se no imaginário adulto (Azevedo, 2005).

Segundo Bernardo, (2005, p. 15), "[...] a ficção oferece menos dúvidas e mais certezas, ao passo que o real nos empresta menos certezas e, portanto, mais dúvidas. [...] se a realidade fosse transparente à linguagem, a ficção não seria necessária." Fala ecoada por Carneiro (2005), segundo o qual a ficção é um disfarce da verdade para que ela possa ser compreendida. 
Histórias podem ser consideradas como um modo de transmitir informações. Ao trazer respostas às relações entre as pessoas e aos conflitos humanos mais complexos, essas narrativas amparam o indivíduo com conhecimento de mundo sobre a vida e a realidade, sendo aspecto indispensável à formação do ser humano em sociedade

\section{Características da literatura infantil e fundamentos da narrativa}

No que tange a configuração da mensagem, conceituados autores da área compartilham fundamentos para a elaboração de histórias, sejam recomendações gerais ou voltadas à Literatura Infantil. Mencionamos aqui recomendações gerais porque, independentemente do meio, elas contribuem para otimizar a história. Como a Literatura Infantil também é narrativa, essas recomendações também são aplicáveis.

De maneira geral, o que King (2005) recomenda para a escrita do romance, igualmente útil à Literatura Infantil, onde o texto não está isento de descrição, é que essa descrição seja bem dosada. Em demasia, atrapalha o leitor; em insuficiência, deixa-o confuso. Junto com McKee (2010) e McDonald (2010), também recomenda que as informações presentes na narrativa precisam ser úteis à progressão da história. É também importante que o tema da história - o que ela tem a dizer - seja sustentado por evidências consistentes ao longo da narrativa (Ibid.) e que informações importantes sejam reveladas nos momentos propícios para gerar tensão e interesse no leitor/espectador (Ibid., McKee, 2010).

Para a Literatura Infantil, recomenda-se o texto ser o mais enxuto possível (Shulevitz, 1985; Salisbury, 2004; Linden, 2011; Nikolajeva \& Scott, 2011; Paul, 2018; Wu, 2018) porque nesse meio costuma-se ter maior protagonismo da imagem, além disso permitir que ela tenha espaço para comunicar as brechas e deixas que as palavras promovam. Isso pode ser considerado em função do texto ter função de contar, e da imagem, como signo mimético, ter função de mostrar (Nikolajeva \& Scott, 2011). Equivalentemente à segunda recomendação geral, texto e imagem não devem ser meramente decorativos e precisam contribuir com a progressão da história (Shulevitz, 1985; Oliveira, 2008; Hunt, 2010; Linden, 2011; Paul, 2017). Um texto polissêmico ${ }^{2}$ é útil às possibilidades de interpretação pelas ilustrações (Linden, 2011), mas tanto texto quanto imagem também podem ser específicos para enfatizar algum detalhe, quando necessário (Shulevitz, 1985). Por fim, conforme muda a faixa etária do leitor, a complexidade das palavras, da enunciação das frases, e a presença de imagens requer adaptação (Coelho, 1997).

Para as narrativas em geral, essas características contribuem para a condução do leitor pela trama, sem deixá-lo acidentalmente confuso e permitindo que assimile as informações apresentadas. Para a Literatura Infantil, elas aprimoram o diálogo texto-imagem sob a linguagem específica do livro ilustrado.

\footnotetext{
2 “Propriedade que uma palavra tem de assumir vários sentidos." (Michaelis On-Line, 2021).
} 


\section{Relações do design da informação com a literatura infantil e os fundamentos da narrativa}

Pode-se encontrar equivalências entre os conceitos apresentados do Design da Informação e as características da Literatura Infantil, bem como os fundamentos da narrativa.

A definição de Jacobson (1999) cita o aumento do entendimento do indivíduo como objetivo do Design da Informação. O autor comenta que a informação pode também ser projetada para persuadir outras pessoas, bem como para compartilhar uma percepção do mundo. Segundo ele (Ibid., p. 1, tradução nossa), "[...] alguns dos primeiros esforços para moldar subjetivamente a experiência humana está nas mitologias e contos narrados por padres, poetas e dramaturgos do mundo antigo."

Observa-se uma relação da contação de histórias com a transmissão de informação e, consequentemente, com a modelagem da experiência humana. São todas operações no âmbito do significado, no campo cognitivo. Quanto à interferência na subjetividade do indivíduo, encontramo-las com facilidade nos contos religiosos das mais variadas crenças, bem como nas fábulas de Esopo, nas histórias de Perrault, de Hans Christian Andersen, nas adaptações de La Fontaine e na coletânea de contos orais realizada pelos irmãos Grimm. Essas histórias estão presentes no repertório das pessoas desde a infância e são frequentemente usadas para ensinar lições para crianças na expectativa de que aprendam o que é certo e errado conforme a história escolhida e a intenção de quem medeia sua contação.

Isso tem relação com o fato de nós, como seres humanos, vermos nas histórias um meio de buscar respostas, de nos compreendermos melhor e, consequentemente, compreendermos o mundo ao nosso redor, dada a abordagem dos aspectos subjetivos e complexos que a literatura faz, como vimos com Azevedo (2005), Bernardo (2005) e Carneiro (2005).

A preparação da informação para que possa ser usada com eficiência e eficácia, como definido por Horn (1999), se encaixa no conceito de utilidade da narrativa como modo de compreensão da realidade. Assim, é possível considerar que as informações, componentes de uma história, precisam ser bem preparadas - bem planejadas, bem organizadas e bem apresentadas - para que possam ser utilizadas com eficiência e eficácia pelo indivíduo receptor.

Horn (Ibid.) também apresenta o conceito de tight coupling, que define não ser possível remover um componente da linguagem visual - conjunto de palavras, imagens e formas, que trabalham juntos - sem prejudicar seu significado. Encontramos a aplicação desse mesmo fundamento na Literatura Infantil na caracterização do livro ilustrado, em que texto e imagem trabalham juntos para a construção de sentido da história e não podem ser dissociados sem comprometer a compreensão da narrativa.

Quanto à transformação de dados em informação, Shedroff define que dados, "para terem valor, precisam ser organizados, transformados e apresentados em um modo que thes dê significado - e que Ihes faz ter valor" (Shedroff, 1999, p. 270, tradução nossa). Como resultado, o que teríamos não seriam apenas dados, mas sim informação, que "[...] representa a transmissão de mensagens que revelam as relações e padrões (o contexto) entre os dados apresentados" (Ibid., p. 272, tradução nossa). 
Encontramos relação desses conceitos com um fundamento da escrita que recomenda ao autor falar a verdade em suas histórias. McKee (2010) define o que são fatos para poder explicar o que são verdades considerando que os primeiros são simples acontecimentos, são neutros e que "uma mera ocorrência não nos leva a lugar nenhum próximo à verdade" (Ibid., p. 25, tradução nossa). Para ele, verdades são interpretações dos fatos, e os mesmos fatos podem ser interpretados de maneiras diferentes por autores diferentes. Pegar um ônibus, fazer uma ligação, são simplesmente fatos no universo diegético ${ }^{3}$ porque essas ocorrências não dizem muito sobre o personagem, seu entorno ou o enredo. Nos exemplos apresentados, esses acontecimentos estão desprovidos de contexto e valor. Leitores/espectadores questionarão: por que o personagem pegou um ônibus? Não podia usar outro transporte? Para quem liga? Em que circunstâncias? O que fala, que tom de voz usa, como responde às palavras ou ao silêncio daquele que está do outro lado da linha? Respostas a essas perguntas, apresentadas diretamente ou nas entrelinhas da história, informam os leitores/espectadores sobre a condição de vida dele, seu caráter, desejos, ambições, e até sobre seu entorno. O modo como o personagem age e reage se consolida como sua verdade no universo ficcional, gerada pela interpretação que o autor faz daqueles fatos, e diferentes autores escreverão diferentes verdades com os mesmos fatos.

Vemos como os fatos, quando contextualizados e com valores agregados se tornam verdade no campo diegético. Enxergamos uma equivalência desses conceitos com os de dados e informação de Shedroff (1999) conforme a figura 3.

Figura 3: Relação dos conceitos de fatos e verdade com dados e informação.

Design da Informação

Shedroff (1999)
Fundamentos da narrativa McKee (2010)

\section{Dados}

são "[...] o material cru que encontramos ou criamos que usamos para construir nossas comunicaçöes."

(Shedroff, 1999, p. 272, tradução nossa)

\section{Informação}

"Ela representa a transmissão de mensagens que revelam as relações e padrões (o contexto) entre os dados apresentados."

\section{Fatos}

"[...] são neutros. [...] O que acontece é fato, não verdade."

(Mckee, 2010, p. 25, grifos nossos. tradução nossa)

\section{Verdade}

"[...] é o que achamos sobre o que acontece." (McKee, 2010 , p. 25, tradução nossa)

(Shedroff, 1999, p. 272, tradução nossa)

Por fim, levamos em conta as características do DI definidas por Redig (2004) para analisar os campos da Literatura Infantil e dos fundamentos da escrita narrativa. Como afirmado

\footnotetext{
${ }^{3}$ Relativo ao universo ficcional. "Ato de narrar ou contar uma história" (Dicionário Priberam da Língua Portuguesa, 2021).
} 
anteriormente, se há preocupação com a determinação do conteúdo da mensagem ( $\mathrm{Ibid}$.), então devemos analisar como ele é configurado. A relação entre esses três campos encontra-se na figura 4.

Onde não havia associação com as características textuais, encontramo-las com as características imagéticas e vice-versa. Para elementos que não apresentavam equivalência com a Literatura Infantil, identificamos associações com os fundamentos da narrativa

Quanto ao receptor, como demonstrado pela constante preocupação com o leitor/espectador, assumimos que tanto a Literatura Infantil quanto os fundamentos da narrativa demonstram foco no receptor.

Quanto à forma, as imagens atendem à característica de analogia por serem análogas ao conteúdo que representam, apesar das variações estilísticas. Os cuidados com descrições e com ambiguidades são fatores contributivos para a promoção da clareza. $O$ texto enxuto o torna conciso. Texto e imagem podem servir à ênfase de algum elemento, cada um a seu modo. Para coloquialidade, que tem a ver com o uso de linguagem comum e acessível, associamos ao cuidado com as palavras e o diálogo delas com a imagem, que se altera conforme a faixa etária do leitor. À consistência associamos a relevância dos elementos transmissores da história, em oposição à mera decoração, ao adorno.

Quanto ao tempo, a revelação de informações importantes nos momentos propícios à adequou à característica de oportunidade. Por fim, a necessidade do tema da história ser sustentado por evidências consistentes em função do tempo, ao longo dela, evidenciou adequação à característica de estabilidade.

Das características levantadas, cordialidade foi a única para a qual não encontramos uma correlação. Julgamos que deve-se ao fato de estar associada a uma comunicação direta com o usuário do artefato ou leitor da mensagem. Ela é evidente quando se solicita ao indivíduo que realize uma ação. Isso não costuma acontecer num livro infantil, nem em um romance ou filme. É possível que possa ser identificado em livros infantis digitais interativos ou em modos interativos desenvolvidos para outras modalidades de transmissão de histórias, o que foge ao escopo desta pesquisa. Pode ser que a cordialidade também seja atribuída ao virar de página do livro, que é a execução de uma ação, considerando que a história deve estimular o leitor a continuar lendo-a, mas isso requer uma pesquisa mais aprofundada.

Necessário ressaltar como toda essa relação evidencia as características do Design da Informação definidas pela SBDI (2020), em especial o planejamento, a configuração e a preocupação com a eficiência da comunicação. 
Figura 4: Relação das características do Design da Informação com as características da Literatura Infantil e dos fundamentos da narrativa.

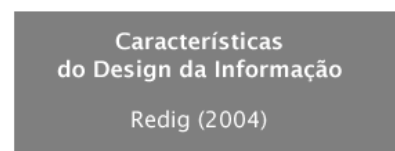

Quanto ao $\quad$ Foco no

$\begin{array}{cc}\text { Quanto ao } & \text { Foco no } \\ \text { destinatário } & \text { receptor }\end{array}$

Quanto
à forma
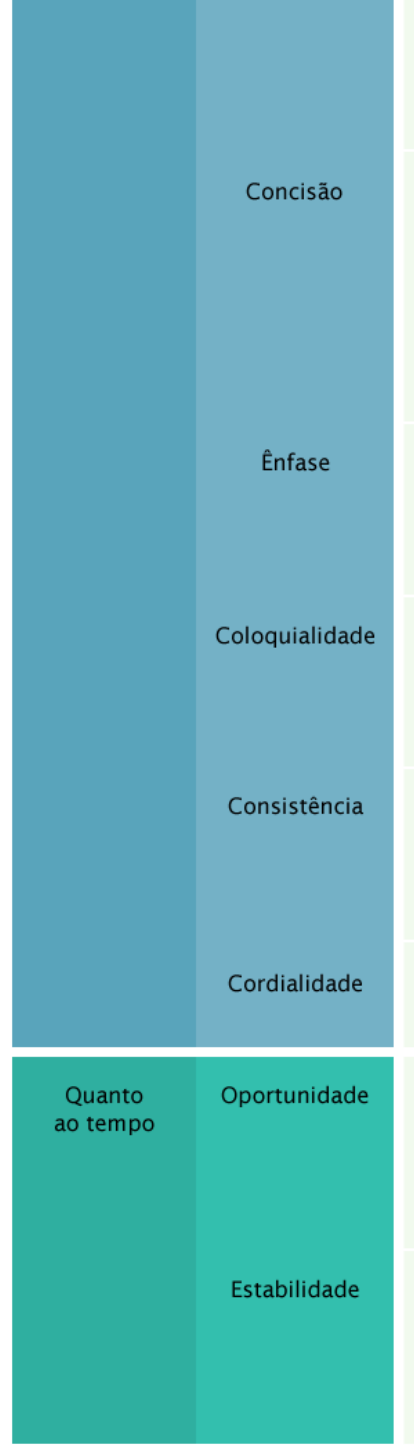

O texto pode enfatizar algum detalhe da imagem. (Shulevitz, 1985)

Pode haver polissemia evitando-se ambiguidade. (Linden, 2011)

O texto deve ser

o mais enxuto possivel.

(Shulevitz, 1985;

Salisbury, 2004:

Linden, 2011

Nikolajeva \& Scott, 2011;

Paul, 2018; Wu, 2018

(Shlevitz, 1985)

Escolha de palavras

e enunciação de maneira

adequada à faia etária

do leitor. (Coelho, 1997)

A imagem pode enfatizar

elementos cruciais

ou dramáticos.

(Shulevitz, 1985)

O diálogo entre texto

e imagem muda conforme

a idade do leitor.

(Coelho, 1997)

Texto e imagem não devem ser meramente decorativos Precisam contribuir com a progressão da história. (Shulevitz, 1985, Oliveira, 2008; Hunt, 2010;

Linden, 2011; Paul, 2017)
Fundamentos da narrativa

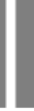

Foco no leitor/espectador, público alvo

Descrição demais ou de menos deixam o leitor confuso. Deve-se encontrar um meio-termo. (King, 2005)
Deve-se evitar passagens desnecessárias à progressão da história. (McKee, 2010 : McDonald, 2010; King, 2015)

\section{Considerações finais}

Buscou-se demonstrar através deste artigo que é possível encontrar equivalências das definições e características do Design da Informação com o campo da Literatura Infantil, bem como os fundamentos da narrativa. 
Ressaltamos a equivalência do conceito de tight coupling de Horn (1999) com o livro ilustrado; dos conceitos de dados e informação de Shedroff (1999) com os conceitos de fatos e verdade de McKee (2010); e a equivalência das características do Design da Informação, de Redig (2004), com as características configurativas da Literatura Infantil e dos fundamentos da narrativa.

Espera-se que este artigo possa fornecer um ferramental teórico para os pesquisadores do Design da Informação em prol de estudos mais aprofundados sobre a Literatura Infantil, contribuindo para a eficiência dos processos de análise e configuração dos livros ilustrados, bem como de outras formas de transmissão de histórias.

Estamos diante de um campo riquíssimo que já foi bastante desbravado por outras áreas do conhecimento. Nesse sentido, nossos estudos caem em terreno extremamente fértil. Uma análise profunda do livro, porém, exigirá do pesquisador interdisciplinaridade essencial. E não é esse conhecimento adicional algo que a pesquisa em Design sempre nos provoca a adquirir?

\section{Agradecimento}

O presente trabalho foi realizado com apoio da Coordenação de Aperfeiçoamento de Pessoal de Nível Superior - Brasil (CAPES) - Código de Financiamento 001.

\section{Referências}

Azevedo, R. (2005). Aspectos instigantes da literatura infantil e juvenil. In I. Oliveira (Org.), O que é qualidade em literatura infantil e juvenil? com a palavra o escritor. São Paulo: DCL, 25-46.

Bernardo, G. (2005). A qualidade da invenção. In I. Oliveira (Org.), O que é qualidade em literatura infantil e juvenil? com a palavra o escritor. São Paulo: DCL, 9-24.

Cambridge University Press. (2021). Boolean | Significado, definição em Dicionário Inglês. Disponível em https://dictionary.cambridge.org/pt/dicionario/ingles/boolean. Acesso em 28 abr. 2021.

Carneiro, F. (2005). A ficção falsa. In I. Oliveira (Org.), O que é qualidade em literatura infantil e juvenil? com a palavra o escritor. São Paulo: DCL, 61-76.

Coelho, N. N. (1997). Literatura infantil: teoria, análise, didática (6ª ed.). São Paulo: Editora Ática.

Dicionário Priberam da Língua Portuguesa. (2021). Diegese. Disponível em https://dicionario.priberam.org/diegese. Acesso em 13 abr. 2021.

Franco, B. de T. (2018). Uirapuru - design gráfico e ilustrações de livro para crianças com baixa visão. Blucher Design Proceedings, 4(1), 360-372. https://doi.org/10.5151/cidi2017-035

Fleck, F. de O., Cunha, M. F. V., \& Caldin, C. F. (2016). Livro ilustrado: Texto, imagem e mediação. Perspectivas em Ciência da Informação, 21(1), 194-206. https://doi.org/10.1590/1981-5344/2390

Gil, A. C. (2008). Métodos e Técnicas de Pesquisa Social (6ª ed.). São Paulo: Editora Atlas.

Horn, R. E. (1999). Information Design: Emergence of a New Profession. In Robert Jacobson (Ed.), Information Design. Cambridge: MIT Press, 15-33. 
Hunt, P. (2010). Crítica, teoria e literatura infantil (C. Knipel, trad.). São Paulo: Cosac Naify.

Jacobson, R. (1999). Introduction: Why Information Design Matters. In: Robert Jacobson (Ed.). Information Design. Cambridge: MIT Press, 1-10.

King, S. (2005). Sobre a escrita: a arte em memórias (M. Teixeira, trad.). Rio de Janeiro: Objetiva.

Lacerda, M. G., \& Farbiarz, J. L. (2016). Uma Proposta de Design na Leitura: Reflexões sobre Sujeitos, Objetos-Livro e Políticas Públicas Para a Formação do Leitor. InfoDesign - Revista Brasileira de Design da Informação, 13(3), 277-290. https://doi.org/10.5151/despro-ped20160405

Lajolo, M., \& Zilberman, R. (2017). Literatura infantil brasileira: uma outra / nova história. Curitiba: PUCPRESS. Ática. (2007). Literatura Infantil Brasileira: História e Histórias (6 ed.). São Paulo: Editora

Linden, S. Van der. (2011). Para ler o livro ilustrado (D. de Bruchard, trad.). São Paulo: Cosac Naify.

McKee, R. (2010). Story: style, structure, substance, and the principles of screenwriting (Edição do Kindle ed.) [E-book]. Harper Collins.

McDonald, B. (2010). Invisible Ink: A practical guide to building stories that resonate (Edição do Kindle ed.) [E-book]. Libertary Co.

Michaelis On-Line. (2021). Polissemia. Disponível em https://michaelis.uol.com.br/modernoportugues/busca/portugues-brasileiro/polissemia/. Acesso em 13 abr. 2021.

Nikolajeva, M., \& Scott, C. (2011). Livro ilustrado: palavras e imagens (C. Knipel, trad.). São Paulo: Cosac Naify.

Oliveira, I. de (Ed.). (2008). O que é qualidade em ilustração no livro infantil e juvenil: com a palavra o ilustrador. São Paulo: DCL.

Paul, A. W. (2018). Writing Picture Books Revised and Expanded Edition. Cincinnati: Writer's Digest Books.

Redig, J. (2004). Não há cidadania sem informação, nem informação sem design. InfoDesign Revista Brasileira de Design da Informação, 1(1), 58-66.

Salisbury, M. (2004). Illustrating Children's Books: Creating Pictures for Publication (1st ed.). Londres: A\&C Black Publishers.

Shedroff, N. (1999). Information Interaction Design: A Unified Field Theory of Design. In R. Jacobson (Ed.), Information Design. Cambridge: MIT Press, 267-292.

Shulevitz, U. (1985). Writing with pictures: how to write and illustrate children's books. New York: Watson-Gupil Publications.

Sociedade Brasileira de Design da Informação (SBDI). Brasil, (2020). Disponível em http://www.sbdi.org.br/definicoes. Acesso em 6 mar. 2021. 
Souza, E. A., Oliveira, G. A. F., Miranda, E. R., Coutinho, S. G., Filho, G. P., \& Waechter, H. da N. (2018). A forma como conteúdo: O caso de Irma Boom. Blucher Design Proceedings, 4(1), 162-171. https://doi.org/10.5151/cidi2017-015

Miranda, E. R., \& Filho, G. P. (2016a). A Narrativa Gráfica Enquanto Medium. InfoDesign - Revista Brasileira de Design da Informação, 13(3), 246-260. https://doi.org/10.5151/despro-ped2016-0400

Oliveira, G. A., Miranda, E. R., Coutinho, S. G., Waechter, H. da N., \& Filho, G. P. (2016b). Alternativas epistemológicas para o design da informação: a forma enquanto conteúdo. InfoDesign - Revista Brasileira de Design da Informação, 13(2), 107-118. https://doi.org/10.4319/lo.2004.49.4.1084

Wu, D. (2018). Entrevista concedida pelo ilustrador Daniel Wu ao pesquisador. In G. M. C. Costa, Desenvolvimento do livro infantil ilustrado "A Aventura De Bernardo": O llustrador como Designer da Comunicação Visual (pp 91-111). Orientador: Adailton Laporte Alencar. Trabalho de conclusão de curso (Bacharelado em Design). UniFBV Wyden, Recife.

\section{Sobre os autores}

Guilherme Mendes Cahú Costa, Mestrando, UFPE, Brasil <guilhermecahu@gmail.com> Solange Galvão Coutinho, PhD, UFPE, Brasil <solange.coutinho@ufpe.br> 